\title{
Crises of Biodiversity and Ecosystem Services in Satoyama Landscape of Japan: A Review on the Role of Management
}

\author{
Yuanmei Jiao ${ }^{1}$, Yinping Ding ${ }^{1}$, Zhiqin Zha ${ }^{1}$ and Toshiya Okuro ${ }^{2, *}$ \\ 1 School of Tourism and Geography Science, Yunnan Normal University, Kunming 650092, China; \\ ymjiao@sina.com (Y.J.); yinpingding222@163.com (Y.D.); zhazhiqinyn@163.com (Z.Z.) \\ 2 Laboratory of Landscape Ecology and Planning, Graduate School of Agricultural and Life Sciences, \\ The University of Tokyo, Tokyo 113-8657, Japan \\ * Correspondence: aokuro@mail.ecc.u-tokyo.ac.jp
}

Received: 4 November 2018; Accepted: 8 January 2019; Published: 16 January 2019

\begin{abstract}
Satoyama is a Japanese term used to describe the traditional rural landscape in Japan. It has changed continuously from overuse to underuse stages under the development of economy and society, which caused the loss of both biodiversity and ecosystem services. In this paper, we summarized the interactions of biodiversity and ecosystem services affected by human management in Satoyama landscape. The results indicate: (1) the concepts of Satoyama forests and Satoyama landscape varied with researchers and their objectives. The most popular one is a mosaic landscape consisting of Satoyama (secondary) forests, rice paddies, grassland, ponds, irrigating systems, and rural settlements; (2) traditional management regimes on Satoyama landscape were the disturbing mechanisms to provide multiple ecosystem services, as well as a series of semi-natural habitats for species; (3) due to significant progress in economy and technology in Japan, the aging problems of farmers, industrialized agriculture, the import of ecosystem services and goods from international markets, and global climate changes eventually caused the simplification of crop plants, the invasion of alien species, the fragmentation of habitats, and the decreasing of ecosystem services; (4) future research should pay more attention to the complex mechanisms of biodiversity crises and ecosystem services at the landscape scale, considering pattern-process relationships.
\end{abstract}

Keywords: Satoyama landscape; concepts; management; ecosystem services; changes; biodiversity loss; overuse; underuse; abandonment; consolidation

\section{Introduction}

Agriculture is a dominant form of land management in the world. It has long been criticized as the major driving force of biodiversity loss [1-3]. However, recent research showed that traditional agricultural landscapes can maintain rich biodiversity and provide a bundle of ecosystem services [4-7]. Generally, the traditional agricultural landscape commonly encompasses the multiple uses of natural, semi-natural, and artificial ecosystems [8], where crop cultivated plots and adjacent vegetation and habitats are often integrated into a well-managed mosaic-like production landscape [9]. Indigenous farmers tend to maintain biodiversity, not only within a cultivated area, but also in natural ecosystems adjacent to their fields, and thus obtain a significant portion of their subsistence requirements of ecosystem services through gathering, fishing, hunting, and other management in habitats surrounding their agricultural plots [10-12].

Nevertheless, the traditional agricultural landscape is rapidly disappearing and facing modern social, political, and economic changes [13], which have caused the loss of both biodiversity and ecosystem services. Altieri [10] studied three kinds of disappearance of traditional agriculture 
landscape. In most cases, it is a consequence of conversion from a subsisting economy to a cash agricultural economy of indigenous communities. During this process, the agricultural activity and policy focused on more fertile and accessible land, then caused the abandonment of traditional, labor-intensive farming of marginal land, particularly in mountain areas [14]. In addition, external economic forces are increasingly influencing production by favoring genetically uniform crops and mechanized agrochemical practices, which has caused the loss or even extinction of landraces and wild plants [15]. In some areas, land scarcity has forced changes in land use, which in turn has caused the disappearance of habitats that formerly maintained useful non-crop vegetation, including wild progenitors and weedy forms of crops. In other cases, the increasing impoverishment and lack of income-generating alternatives for rural populations cannot afford conservation with limited land [16]. Actually, all the three situations will result in the loss or crises of biodiversity and ecosystem services, because abandoning or insufficient traditional management cannot maintain biodiversity and essential ecosystem services at the original level.

Traditional Satoyama landscape in Japan was a mosaic of agricultural land use systems created at least 3000 years ago [17]. It was used to be a nature-harmonious system supporting high biodiversity and bundles of ecosystem services. Nevertheless, from the 1960s, the industrialization and globalization of Japan's economy and society changed the complex interdependence among components of Satoyama landscape. Increasing imports of many kinds of ecosystem services from the international market, along with the aging problem, caused the underuse and abandonment of Satoyama landscape, thus leading to the disappearance of cultural landscapes, decline in agriculture, as well as the loss of biodiversity.

This paper reviews the main studies carried out in Satoyama landscape with the purpose of: (i) providing an overview of the concepts and components of Satoyama landscape; (ii) summarizing the traditional management practices on the provision of ecosystem services and habitat series for species; (iii) examining biodiversity crisis caused by both habitat loss and fragmentation under modern management; (iv) identifying the relationships between biodiversity loss, ecosystem services, and human well-being; and (v) recommending further research oriented towards the revitalization of Satoyama landscape, which can benefit international conservation of cultural landscapes in East Asia with similar rice culture systems.

\section{Concepts, Components, and Biodiversity Crisis of Satoyama Landscape}

\subsection{Concepts and Components of Satoyama Landscape}

Nowadays, the concept of Satoyama has changed significantly, as well as its coverage areas (Table 1). It depended on whether one defines it as the managed forest alone, the managed landscape used by a single family, the landscape used by an entire village or cluster of villages [18], or the traditional rural landscape in the whole of Japan [19].

In Japanese, 'Sato' means village or settlement and 'Yama' means mountain or hill. According to Takeuchi et al [19], in 1759, the term Satoyama was first used by a Kiso area assistant wood manager, Hyouemon Teramachi, who described Satoyama as mountainous landscapes close to rural villages. In early the 1960s, a forest ecologist Tsunahide Shidei proposed the idea of Satoyama as mountains near the village and in 2000 he defined the concept of Satoyama as agricultural woodland, or Satoyama forests and woodlands. According to ISI web of Science, many authors accepted the original definition and referred to it as Satoyama forests [20-22]. This can be verified by the nominated sites of "The Top 100 Japanese Rural landscapes", in which Forest Type sites account for 88\% [23].

After 2000, more and more research on Satoyama took a broader concept of Satoyama as a mosaic of secondary forests (Satoyama forests), rice paddies, crop fields, grasslands, streams, ponds, and reservoirs, with a landscape ecological view [24,25]. Fukamachi et al [26] described Satoyama landscape as "traditional, rural landscapes, which are social and ecological networks of a village and its surroundings, which include agricultural lands, open forest lands and forests, and which have maintained a high diversity of plants, insects, and small-to-medium-sized animals." All these concepts 
described the components and their spatial arrangement of the Satoyama landscape, although they vary regionally throughout the country. In summary, the four essential components, including secondary forests, rice paddies, settlements, and water areas, are the main ecosystems of Satoyama landscape.

Table 1. The concepts and components of Satoyama landscape.

\begin{tabular}{|c|c|c|c|c|}
\hline Authors & Time & Concepts and Components & Area & Scale \\
\hline Tokoro [27] & 1759 & Mountainous landscapes close to rural villages & & \\
\hline Shidei [28] & Early 1960s & Mountains near the village & & Village \\
\hline Tabata [29] & 1997 & $\begin{array}{l}\text { Satoyama consists of a mosaic of mixed forests, rice } \\
\text { paddy, dry rice fields, grasslands, streams, ponds, } \\
\text { and reservoirs for irrigation. }\end{array}$ & $\begin{array}{l}\text { Edo era, } 1.1-1.5 \text { ha per family } \\
\text { Satoyama forests, and } 5 \text { ha } \\
\text { Satoyama landscape per family }\end{array}$ & Village \\
\hline $\begin{array}{l}\text { Fukamachi and } \\
\text { Nakashizuka [30] }\end{array}$ & 1998 & $\begin{array}{l}\text { A place providing public goods such as scenic beauty } \\
\text { and recreation, and conserving biodiversity. }\end{array}$ & & \\
\hline Shidei [31] & 2000 & Agricultural woodland & & $\begin{array}{c}\text { Forest } \\
\text { ecosystem }\end{array}$ \\
\hline Washitani [17] & 2001 & $\begin{array}{l}\text { A traditional rural sustainable ecosystem common in } \\
\text { pre-industrialized Japan. A mosaic of land uses, } \\
\text { including forests, grasslands, farms, ponds, and creeks }\end{array}$ & $\begin{array}{l}\text { In } 1869, \text { Shishizuka-Ooike site, } \\
0.1 \text { ha crop land needs } 1 \text { ton of } \\
\text { foliage or litter. Paddy fields, } \\
\text { crop lands, forests, grasslands, } \\
\text { resident areas occupied } 30 \% \text {, } \\
29 \%, 34 \%, 3 \% \text {, and } 5 \% \text { in } \\
\text { a } 150 \text {-ha village, respectively. }\end{array}$ & $\begin{array}{l}\text { Ecosystem } \\
\text { lowland } \\
\text { village }\end{array}$ \\
\hline Fukamachi et al. [26] & 2001 & Traditional, rural Japanese landscapes & $67 \%$ of total Japan's area & Regional \\
\hline Takeuchi et al. [19] & 2003 & $\begin{array}{l}\text { The rural landscape composed of Satoyama (forest), } \\
\text { farmlands, settlements, and reservoirs }\end{array}$ & $60,000-90,000 \mathrm{KM}^{2}$ & National \\
\hline $\begin{array}{l}\text { Kobori and } \\
\text { Primack }[18]\end{array}$ & 2003 & $\begin{array}{l}\text { Satoyama refers to a larger landscape, which consists of } \\
\text { a cluster of villages, community forests, rice paddy } \\
\text { fields, grasslands, wetlands, and the remaining } \\
\text { agricultural landscape used to supply the needs of } \\
\text { an entire community. }\end{array}$ & & Regional \\
\hline MEGJ [32] & $2008 \mathrm{a}$ & $\begin{array}{l}\text { Satoyama landscape is consist of vegetable fields, rice } \\
\text { fields, irrigation ponds, ditches, grassland, woodland, } \\
\text { and residential areas distributed in a complex } \\
\text { mosaic-like pattern. }\end{array}$ & $\begin{array}{l}\text { Secondary forests as the core of } \\
\text { Satochi-Satoyama area accounts } \\
\text { for about } 20 \% \text { of the total } \\
\text { national land, and about } 40 \% \\
\text { when agricultural lands are } \\
\text { included. }\end{array}$ & National \\
\hline Morimoto [33] & 2010 & $\begin{array}{l}\text { Satoyama refers to an area between urban areas and } \\
\text { primeval nature, consisting of secondary forests, } \\
\text { paddies, farmlands, grasslands, and irrigation ponds } \\
\text { around settlements. It has been studied in four fields: } \\
\text { (1) Woodland as a backyard; (2) biodiversity hotspot; } \\
\text { (3) sustainable natural resource management (systems); } \\
\text { and (4) beautiful ancestral homeland. }\end{array}$ & $\begin{array}{l}\text { Includes } 800 \text { million ha of } \\
\text { secondary forests, } 700 \text { million ha } \\
\text { of agricultural areas, possess up } \\
\text { to } 40 \% \text { of Japan's territory. }\end{array}$ & National \\
\hline Takeuchi [13] & 2010 & $\begin{array}{l}\text { (1) Narrowly defined, Satoyama refers to secondary } \\
\text { woodlands and grasslands near human settlements that } \\
\text { have traditionally used these lands as coppices and } \\
\text { meadows for fuel, fertilizer, and fodder. (2) In the } \\
\text { broader sense, Satoyama (landscape) encompasses farm } \\
\text { fields, rice paddies, irrigation canals and ponds, and the } \\
\text { settlements themselves. }\end{array}$ & & National \\
\hline
\end{tabular}

\subsection{Biodiversity Crisis in Satoyama Landscape}

Biodiversity in Japan is originally rich and characterized by relatively high endemism and thus designated as a biodiversity hotspot in 2005 [33]. The number of known species is estimated to be over 90 thousand $[30,32,34]$. However, the same as global trends of biodiversity loss happened in many countries after industrialization, Japan also experienced three obvious biodiversity crises, including overuse, underuse, and alien species invasion, respectively. In total, there are 3155 species threatened with extinction, with nearly $40 \%$ of land mammals and vascular plants, $60 \%$ of reptiles, and $80 \%$ of amphibian species [32]. The second crisis, namely the underuse of the Satoyama landscape, is the effects caused by reduced or discontinued human management on nature. In Japan, rural area possesses $40 \%$ of the national land and over $40 \%$ of Japanese biodiversity hot spots are located in rural area. Satoyama plays an important role in biodiversity conservation that over half of the species on Japan's Red List live in Satoyama areas [32]. In the traditional Satoyama landscape, secondary forests (fuel wood forests, farm forests, and etc.) and secondary grasslands had been maintained as necessities for economic activities. Such human-made areas had grown a variety of living things specific to each environment. When they have been free from human disturbances, ecosystems have lost their diversity. 
Thus, many animals, birds, and plants that have lived in Satoyama areas are designated as threatened species. Studies suggest that so far many wader and grassland bird species have declined in numbers or reduced their distribution in Japanese agricultural landscapes [35]. For example, grey-faced buzzard eagles (Butastur indicus), living mainly in Satoyama areas, were designated as a threatened species [32]. At present, the crisis is continuously expanding because of aging problems.

\section{Habitat Series and Ecosystem Services of Satoyama Landscape Under Traditional Management}

\subsection{Traditional Management and Habitat Series}

To get food and other daily necessities from Satoyama landscape, farmers promoted continuous management of it, which is called human disturbances by biologists [36,37]. During the managing process, multiple habitat patches were created by repeated periodic cutting, coppicing, mowing, collecting, irrigating, draining, and harvesting of firewood, fodder, litter, and food in natural or semi-natural land at a village scale (Figure 1). These habitat patches include common forests, pine forests, coppice forests and oak forests, giant bamboo forests, inbatsuchi, thatch fields, grasslands, shifting cultivation land, ploughed and crop fields, rice paddy and terraces, streams, ponds, reservoirs, and also settlement $[17,19,26,38]$. The diverse habitats resulting from management regimes sustained rich biodiversity with half of threatened species in Japan [39-42].

Rice paddy fields in Satoyama landscape provided a unique spatial and temporal habitat mosaic for biodiversity [43] (Figure 1). First, traditional rice paddy areas are always composed of rice paddies, ponds, reservoirs, and streams or earth channels for irrigating and drainage [44], thus forming a complex wetland system and serve as multiple habitats for aquatic organisms. Second, rice paddies themselves have many types of species, such as rice paddies in flat plains, rice terraces in hilly and mountainous areas, wetland-like paddies, which are flooded due to spring water or high groundwater tables, and paddies at fallow stage. Third, each plot of rice paddy is composed of paddy and levee; the paddy is supplied with water from spring to early summer, irrigated intermittently after a short drainage in summer, and drained from autumn to next spring in a well-drained manner. Therefore, the large area of flooded rice fields in the planting period contributed to the high richness and abundance of agricultural wetland species, while in winter served as suitable habitats for some land birds [35,45], seed-eaters [46], and invertebrates for invertebrate-feeders [47,48]. Fourth, the variation in habitat characteristics created by wet-dry cycle of rice cultivation also allows agricultural bird species to use different types of landscapes between seasons [44].

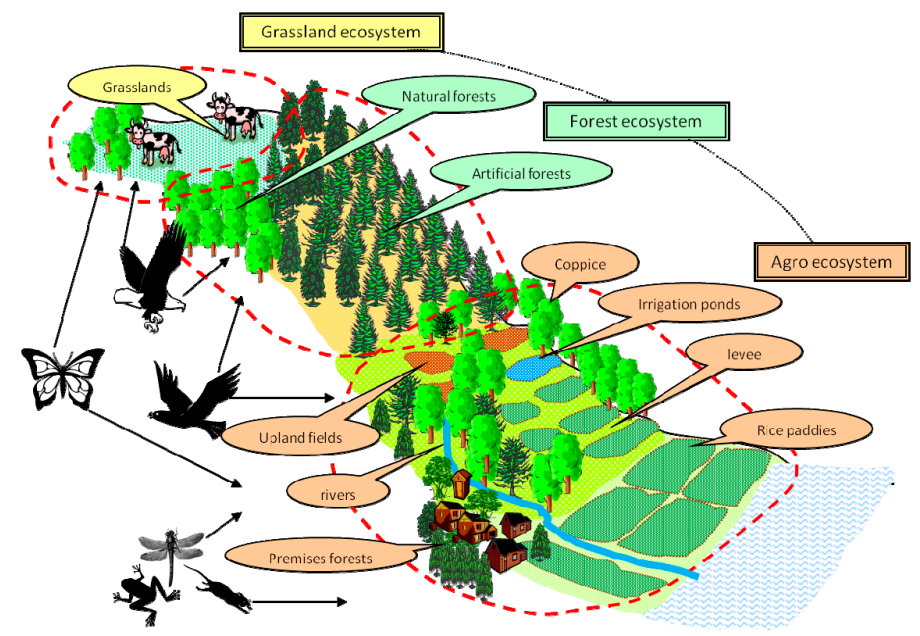

Figure 1. Satoyama landscape is composed of grassland, forest, and agro-ecosystems; it has a set of habitats for rich biodiversity and bundles of ecosystem services for human well-being under traditional management. 
Considering the succession series of forest husbandry, there are nine periodic habitat series in forest ecosystems (Figure 2). First, frequent cutting and thinning of woodlands led to the domination of dwarf pines and coppices, and decreased the occurrence of invasive species and increased forest floor species diversity $[49,50]$. Second, collecting fallen leaves for fertilizer as well as the regular cutting of deciduous forests supports many species of spring and summer wildflowers, which can survive only when the foliage is thin, and sunlight is able to reach the forest floor. These species cannot push their way through a deep layer of fallen leaves, or grow in the darkness of evergreen forest, so they are dependent on traditional management practices [18]. Third, harvesting mixed Japanese oak (Quercus serrata) and Japanese chestnut oak (Quercus acutissima) in deciduous broadleaf forests for fuel wood and charcoal prevented their succession into dense laurel forest (potential climax type for western Japan), ensuring greater diversity [18].

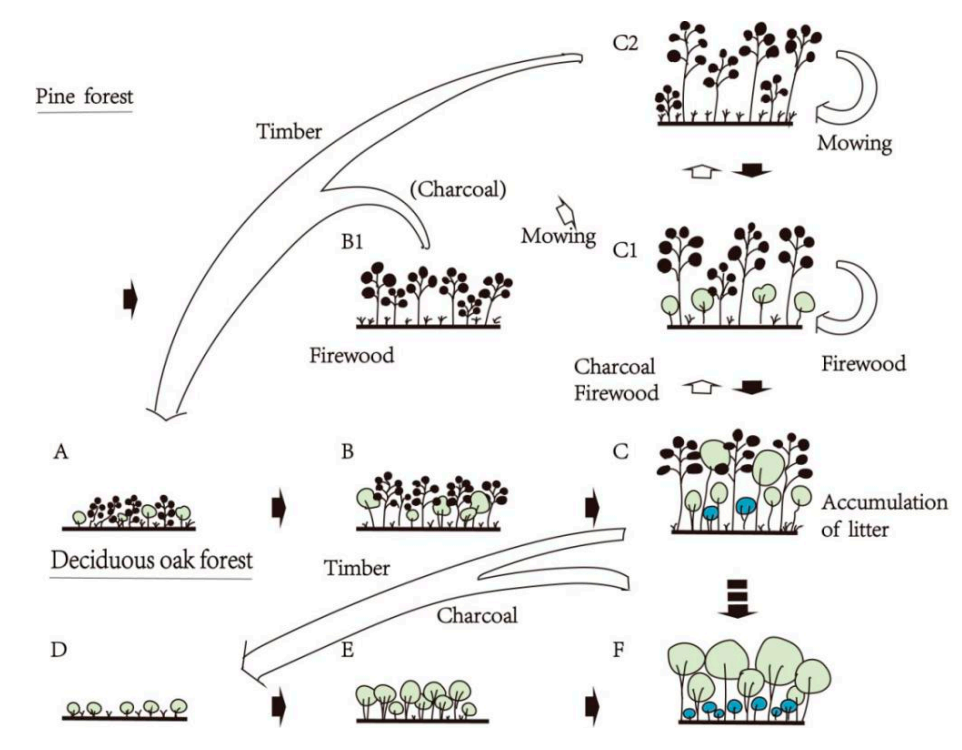

Figure 2. Scheme of a traditional utilization and succession series of Satoyama forests in Japan. The blank arrows signify the utilization and the solid one indicates succession (Redraw from [51]).

In addition, Human intervention of grassland was important for maintaining diversity of herbaceous plant species by preventing invasion of shrubs, lianas, and trees [17], and their succession into the region's potential climax vegetation [52]. Grasslands that are rich in wildflowers and insect species have been maintained by cutting grass for agricultural fertilizer, thatch for construction, bedding, and hay for domesticated animals [18]. As another semi-natural grassland, open secondary forest floor is a habitat for many grass species created by people's cutting of trees and mowing of the understory layer [52].

Furthermore, Satoyama landscape has many kinds of edge-related habitats, especially the semi-aquatic wetland for many species, such as ground beetles [53], giant water bugs, and frogs [25] (Figure 1). Studies have shown that the boundary region between forests and rice fields is a key habitat for plants [54], insects (such as the Genji firefly) [55,56], birds (such as the grey-faced buzzard) [35,45,57], and mammals [58]. Most important of all, the mosaic of landscape components served as habitats easy for species that need multiple habitats [43,59].

\subsection{Traditional Management and Multiple Ecosystem Services}

Traditional Satoyama landscape was the homestead of farmers before the 1960s. Farmers maintained it as their life supporting system to get rice, vegetables, timber, firewood, and other ecosystem services through sustainable management $[13,26,60]$. Each element in the Satoyama landscape was used as sources of daily life necessities via planting, ploughing, cutting, coppicing, and so on (Table 2). Taking the coppice forests as an example, they were used to provide fuel wood and charcoal by periodic cutting of trees and shrubs and produce edible plants and mushrooms by 
collecting. To fertilize rice paddies, organic fertilizers, such as forest litters and composts, were gathered from secondary forests, inbatsuchi, and grasslands, thus, to generate the supporting services of nutrient cycling. To irrigate rice paddy, the five types of waters, including permanent and temporary pools, ditches, rice paddies, and marsh [25], were systematically managed to control floods and generate hydrological regulating services. In addition, the flowering plant species in grasslands, rice paddy levees, as well as rice itself, can be served by bees to support pollination services [61]. The grassland as the habitat of ground beetles also supports regulating services of bio-controlling of pests.

Satoyama landscape also has many kinds of cultural services $[23,62,63]$. It is a beautiful place for seasonal singing of birds, frogs, and insects, as well as clean air and pure water [33]. It is a powerful source of inspiration, imagination, and creativity of the Japanese people who have a feeling of deep emotional attachment to Satoyama [33]. It helped to develop various food cultures unique to each region, with products such as "tsukemono" (traditional Japanese pickles), "miso" (fermented soybean paste), soy sauce, and "sake" (Japanese rice wine). These kinds of food are produced from complicated combinations of micro-organisms and ingredients indigenous to each region, and thus represent unique integrations of nature and culture [64]. Furthermore, isolated trees and hedges are closely linked with cultural features of local daily life in suburban Satoyama landscape [65].

Table 2. Traditional management and ecosystem services and goods of Satoyama landscape.

\begin{tabular}{|c|c|c|c|}
\hline & Distribution Within Landscape & Management & $\begin{array}{l}\text { Ecosystem } \\
\text { Services/goods }\end{array}$ \\
\hline $\begin{array}{l}\text { Common } \\
\text { forests }\end{array}$ & $\begin{array}{l}\text { Located in areas without roadways, } \\
\text { Beech, and high elevations remote from } \\
\text { the village }\end{array}$ & $\begin{array}{l}\text { Shared ownership, reserved for emergency use: logged } \\
\text { as cash reserves, needed for reconstructing damaged } \\
\text { homes while fires happened }\end{array}$ & $\begin{array}{l}\text { Emergency use: cash } \\
\text { reserves, } \\
\text { reconstructing } \\
\text { damaged homes }\end{array}$ \\
\hline $\begin{array}{l}\text { Conifer } \\
\text { plantations }\end{array}$ & $\begin{array}{l}\text { Forests of Japanese cedar and Japanese } \\
\text { cypress, located in units of high } \\
\text { roadway density and shorter time } \\
\text { distance from the village }\end{array}$ & $\begin{array}{l}\text { Constant clearing of underbrush and thinning, } \\
\text { according to the growth stages. }\end{array}$ & Timber production \\
\hline $\begin{array}{l}\text { Secondary } \\
\text { forests } \\
\text { coppice } \\
\text { forests }\end{array}$ & $\begin{array}{l}\text { Located mainly in the north and west } \\
\text { sections of the area }\end{array}$ & $\begin{array}{l}\text { Periodically logged (every } 20 \text { to } 40 \text { years) as fuel wood, } \\
\text { and regenerated without the need of intensive } \\
\text { management. The management techniques include } \\
\text { periodic, partial or small clear-cutting, by litter removal, } \\
\text { or by shrub cutting. }\end{array}$ & $\begin{array}{l}\text { Fuel-wood, charcoal, } \\
\text { mushrooms. }\end{array}$ \\
\hline $\begin{array}{l}\text { Giant } \\
\text { bamboo } \\
\text { forests }\end{array}$ & $\begin{array}{l}\text { Closer to residential areas and agricultural } \\
\text { lands within the middle elevation ranges } \\
\text { with less roadway densities. }\end{array}$ & Intense, careful management for long periods of time. & $\begin{array}{l}\text { Edible young shoots, } \\
\text { making items of } \\
\text { bamboo for daily life } \\
\text { and agriculture }\end{array}$ \\
\hline Inbatsuchi & $\begin{array}{l}\text { Open forestland strips in belts of } \\
\text { approximately } 10 \mathrm{~m} \text { width, located } \\
\text { primarily on the south end of and along } \\
\text { the borders of rice fields, in units of } \\
\text { relative flatness and within the narrow } \\
\text { range of the lower elevations. }\end{array}$ & $\begin{array}{l}\text { Grasses and woody plants were clipped by farmers who } \\
\text { own rice fields nearby at the base every year to every } 5 \\
\text { years in order to maintain sunlight for the fields, and the } \\
\text { chipped ends were used as organic fertilizer }\end{array}$ & $\begin{array}{l}\text { Organic fertilizer, } \\
\text { sunlight for fields }\end{array}$ \\
\hline $\begin{array}{l}\text { Thatch } \\
\text { fields }\end{array}$ & $\begin{array}{l}\text { Open forestlands where dwarf bamboo } \\
\text { grew thickly. Located in various places, } \\
\text { either on steep or gentle hills, and either } \\
\text { remote or close to the village }\end{array}$ & $\begin{array}{l}\text { Inhabitants gathered together on predetermined days to } \\
\text { collect enough dwarf bamboo needed for mending their } \\
\text { roofs, incorporating an annual rotation system } \\
\text { for repairs. }\end{array}$ & $\begin{array}{l}\text { Thatch roofs made } \\
\text { of bamboo }\end{array}$ \\
\hline Grasslands & $\begin{array}{l}\text { In gentle slopes and in mid-elevation } \\
\text { ranges, lush fields in proximity to rice } \\
\text { fields, and with relatively small and flat } \\
\text { valleys; ridges are from } \\
1200 \mathrm{~m} \text { to } 1600 \mathrm{~m} \text { altitude. }\end{array}$ & $\begin{array}{l}\text { Young trees and grass shoots were collected each year as } \\
\text { organic fertilizer for arable lands; a herd of cattle needs } \\
\text { 1ha of grassland. } \\
\text { Controlled burning and mowing }[66,67]\end{array}$ & $\begin{array}{l}\text { Organic fertilizer for } \\
\text { arable lands, forages } \\
\text { feeding horses and } \\
\text { cattle. Roof material. }\end{array}$ \\
\hline $\begin{array}{l}\text { Shifting } \\
\text { cultivation } \\
\text { land }\end{array}$ & Relatively steep inclinations & $\begin{array}{l}\text { Set fires to common forests in mountains, starting at the } \\
\text { top and moving downward, crops grown for roughly } \\
3 \text { years }\end{array}$ & $\begin{array}{l}\text { Buckwheat, soybean, } \\
\text { Japanese radish }\end{array}$ \\
\hline Crop fields, & Relatively flat areas without irrigation & Ploughing, planting, and harvesting. & Vegetables, crops \\
\hline $\begin{array}{l}\text { Rice fields, } \\
\text { rice paddy, } \\
\text { rice terraces }\end{array}$ & $\begin{array}{l}\text { Slopes with available irrigation water, } \\
\text { shallow valley networks with flat } \\
\text { bottoms called 'Yato' or 'Yatsu' are } \\
\text { suitable sites for paddy cultivation. }\end{array}$ & $\begin{array}{l}\text { The schedules of water management in rice paddies are } \\
\text { different in different regions and locations. Rice paddies } \\
\text { are supplied with water from spring to early summer, } \\
\text { irrigated intermittently after a short drainage in summer, } \\
\text { and drained from autumn to next spring in a } \\
\text { well-drained manner. On the other hand, in an } \\
\text { ill-drained manner, paddies are kept flooded due to } \\
\text { spring water or high groundwater tables. }\end{array}$ & Rice \\
\hline $\begin{array}{l}\text { Water } \\
\text { system }\end{array}$ & $\begin{array}{l}\text { Ponds, creeks, paddy fields, reservoirs, } \\
\text { channels, and irrigating systems }\end{array}$ & $\begin{array}{l}\text { Ponds, creeks, and paddy fields were all designed as natural } \\
\text { drainage systems with minimal artificial modification. } \\
\text { Paddies, the largest component of the water system, are } \\
\text { temporary waters, in which seasonally fixed water } \\
\text { management has been maintained for a long time [68]. }\end{array}$ & $\begin{array}{l}\text { Water for rice } \\
\text { planting and fish, } \\
\text { water plants for } \\
\text { green manure }\end{array}$ \\
\hline
\end{tabular}




\section{Habitats Loss and Fragmentation in Satoyama Landscape Under Modern Management}

\subsection{Habitats Loss Caused by Changes of Society and Economy}

Around the 1960s, Japan has experienced rapid economic growth with the revolutions of fuel, fertilizer, transportation, housing, and agriculture technologies, which in turn caused either the abandonment or intensification of all kinds of traditional land use types [39,69,70]. The abandonment of grassland, shifting cultivating land, charcoal forest land, crop land, and rice terraced fields less favoured by farmers, eventually led to the loss of various types of habitats and then threatened many species [17], including the extinction of many common species in traditional Satoyama landscape, such as herbs [70], butterflies [71,72], dragonflies [73], Genji-firefly [74,75], birds [35,76], ground beetles [53], etc.

Actually, during the two decades from 1960 to 1980, the land used for fuel wood, charcoal forest, thatch field, grassland, and shifting cultivating land in Satoyama woodlands has firstly decreased, and ultimately disappeared due to the widespread use of fossil fuel, electricity, and chemical fertilizer, and the plantation of timber woods (pine, cedar, oak) to produce logs or charcoal. The secondary forests have faced insufficient management, thus causing the loss of habitat and then species.

Cropland in Satoyama landscape also faced significant loss, owing to the aging problems and import of foods from international markets (Figure 3). Studies on abandonment of rice paddies and the related impacts on biodiversity show that: (1) Abandoned rice paddy fields leads to vegetation succession affected by soil moisture conditions related to micro-landform, litter accumulation, the growth form of dominant species. and the levee slope vegetation as a seed source [77]. (2) Grey-faced Buzzard-eagle used cultivated paddy fields as hunting grounds more frequently than uncultivated paddy fields [78] and hunted most frequently at sites covered with shorter vegetation [76,79]. (3) Abandonment of rice cultivation in Satoyama landscape directly reduces edge densities between forests and rice fields [57] but increases forest cover instead. (4) Abandonment of cultivated land also caused the invasion of cultivated (seed) species because ploughing history influences edaphic conditions, in particular causing a thicker soil horizon with a coarser texture, increasing the water-holding capacity and nutrient availability, and so it may determine the success of invading early plants [80]. (5) To restore the typical weed communities in abandoned rice paddy fields, reintroduction of rice culture with tillage, plough, and water management is efficient with a rotation of 2-year cycles [81].

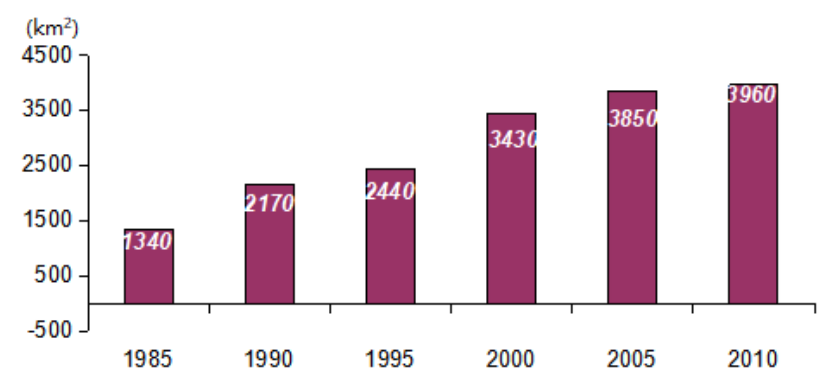

Figure 3. Abandoned cropland in Japan from 1985 to 2010.

\subsection{Habitat Degradation and Fragmentation Caused by Intensive Management and Consolidation}

Beside the abandonment, plantation of commercial timber and transformation to urbanization of partial Satoyama landscape, the reserve was usually changed into industrialized agricultural land. Its' typical feature is high inputs of chemical fertilizers, pesticides, and intensive management to maintain high yield of a single crop-species.

To reduce labour cost and improve soil quality of crop land, many kinds of agricultural infrastructure and strategies had been tried, such as consolidation of ditches and paddy levees, banks of lakes, ponds, and river, and construction of drainage and irrigating systems, as well as field paths (Figure 4). In 2009, the consolidated rice paddy possessed $64 \%$ of the total 25,100 $\mathrm{km}^{2}$ area. Many dry lands are also intensified or significantly modified from traditional land use types to industrialized 
ones. These consolidating infrastructure resulted in the degradation and fragmentation of multiple habitats in rice paddy fields and dry land regions. Therefore, it became another serious threat for species in Satoyama landscape. Table 3 summarized the effects on biodiversity of modern intensive management and consolidation in agriculture.
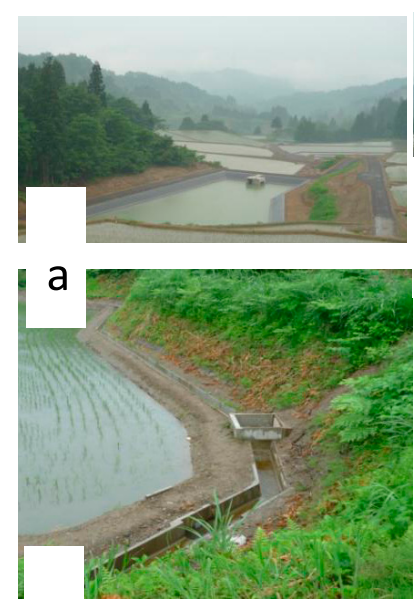

b

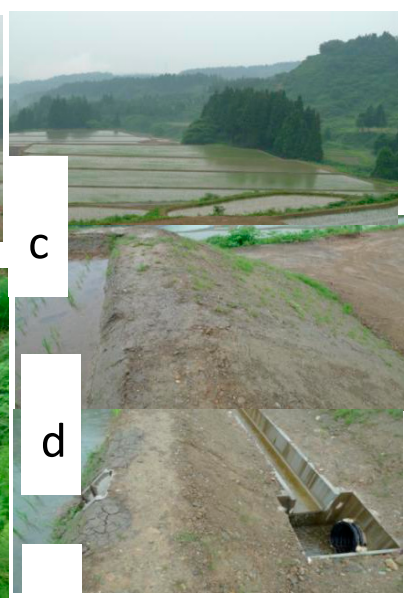

e

Figure 4. Consolidated farmland, irrigating system, pond, and road. (a), (b), (c), (d), and (e) are consolidated pond bank, rice paddy, irrigation canal, paddy levee, and drainage pipe in Niigata Prefecture, respectively.

Table 3. Impacts of intensive management and consolidation on biodiversity in Satoyama landscape.

\begin{tabular}{|c|c|}
\hline $\begin{array}{l}\text { Intensive Management } \\
\text { and Consolidation }\end{array}$ & Effects on Biodiversity \\
\hline $\begin{array}{l}\text { Consolidation of } \\
\text { paddy fields }\end{array}$ & $\begin{array}{l}\text { (1) Great egret, little egret, and cattle egret observed were small and no differences in using } \\
\text { old- and new-style paddy fields. Nevertheless, intermediate egret, which was listed as } \\
\text { a "rare" species in the Red Data Book of Japan, showed a periodic preference for old-style } \\
\text { paddies, namely, from the beginning of May to late May and from July to August, } \\
\text { the old-style paddies are preferred, but from late May to end of June, there is no } \\
\text { difference [82]. (2) More crayfish, loach, and frogs (three species combined) were found in } \\
\text { old-style areas, but no significant differences were recorded for tadpoles [82]. (3) Both } \\
R \text {. porosa and R. japonica favour old-style areas, while most tadpoles in new-style paddy } \\
\text { fields were H. japonica because of their climbing ability to cross new ditches [82,83]. }\end{array}$ \\
\hline Consolidation of ditches & $\begin{array}{l}\text { (1) The numbers of frogs, tadpoles, and fish (other than loach) were all significantly greater } \\
\text { in old-style ditches [82]. (2) The modification of irrigation ditches made it difficult for } \\
\text { firefly larvae to find ditch walls that are suitable for spawning landing in the water [75], } \\
\text { as well as for underground burrowing [74]. For example, in Ichikai Town, Japan, } \\
\text { the number of firefly adults was decreased dramatically from } 2006 \text { to } 2007 \text { at the station } \\
\text { where bank protection works were carried out along a valley at } 2005 \text { [59]. }\end{array}$ \\
\hline $\begin{array}{l}\text { Consolidation and } \\
\text { abandonment of } \\
\text { paddy levees }\end{array}$ & $\begin{array}{l}\text { The species richness and species components of traditional "soil", "abandoned", and } \\
\text { "stone" levees were more diverse than the "concrete" and "consolidated" ones. The "Soil" } \\
\text { type levees contained various woody plant species and included more diverse and } \\
\text { indigenous plant species than "abandoned" type levees. While the "consolidated" levees } \\
\text { contained more introduced species and less plant biodiversity [84]. }\end{array}$ \\
\hline $\begin{array}{l}\text { Construction of artificial } \\
\text { shore and bank protection } \\
\text { of lakes, ponds, and river }\end{array}$ & $\begin{array}{l}\text { (1) A well-preserved eco-tone along the shoreline of the pond due to hydrological gradient } \\
\text { is most responsible for the richness of hydrophyte species [85]. Such kinds of eco-tone } \\
\text { include gradual shifts from submerged zones to floating-leaved zones, and then to } \\
\text { emergent plants zones. Construction of artificial shore protection of lakes and ponds } \\
\text { caused the loss of such eco-tone and contributed to the fact that one third of hydrophyte } \\
\text { species in Japan were threatened [17]. (2) Increased river management for flood control is } \\
\text { one of the habitat loss issues of Fujibakama (Eupatorium fortunei), a symbol of the beauty of } \\
\text { nature and the objects of intense poetic sentiments from ancient times among "Seven } \\
\text { Autumn Wildflowers" beloved by the Japanese [18]. }\end{array}$ \\
\hline $\begin{array}{l}\text { Integrated impacts of } \\
\text { intensive agricultural } \\
\text { management on } \\
\text { multi-habitat organisms }\end{array}$ & $\begin{array}{l}\text { (1) A combination of forests for adults and various lentic and lotic habitats for larvae, } \\
\text { e.g., the pond, with rich eco-tone vegetation, creeks, and paddy fields, constitutes } \\
\text { a high-quality habitat for a variety of dragonfly species. Therefore, environmental } \\
\text { degradation of these habitats is the major threat to dragonflies [17,73]. (2) Amphibians also } \\
\text { need the exquisite combination of forests with diverse wet habitats [17]. }\end{array}$ \\
\hline
\end{tabular}


To sum up, the consolidation of all kinds of "boundary" or narrow "corridor-like" components in Satoyama landscape did impact the species dependent on these marginal habitats. The evidence reviewed by Amano [35] (2009) from the earlier studies on effects of agricultural intensification on farmland bird species has shown the potential mechanism of population decline caused by the consolidation of ditch and drainage systems (Figure 5).

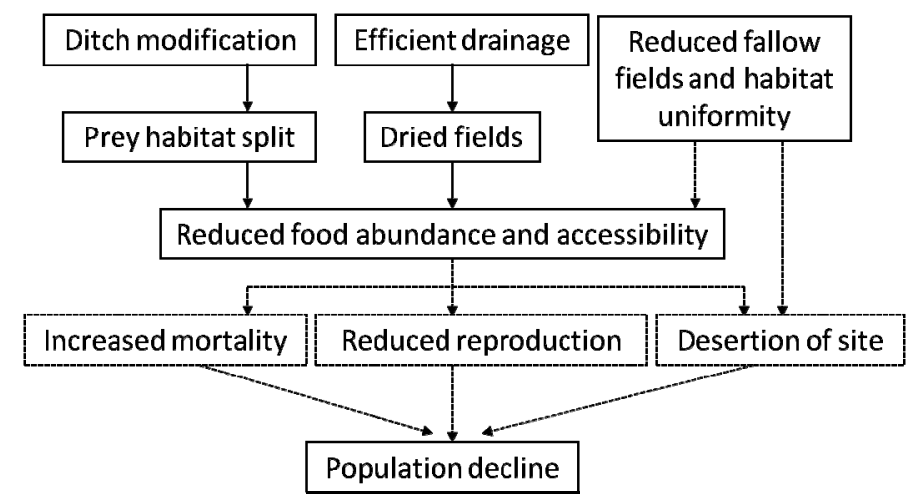

Figure 5. Population decline in waders and egrets caused by agricultural consolidation. Relationships that have not been revealed by earlier studies but are merely suspected are shown in broken lines (Redraw from Amano 2009) [35].

\section{Discussion}

Indicating and interpreting loss of biodiversity is problematic because neither the processes involved nor the evaluation of impacts on environmental values are well understood [14]. However, attempts to reveal it has long been conceived as an international scientific front. Although the state of biodiversity formed by vast and diverse interconnection and character is not well understood, and fundamental knowledge for assessment and countermeasures based on scientific recognition is lacking in Japan [32], the extensive studies reviewed above already revealed a lot of evidence on the potential interactions between biodiversity loss and ecosystem services in Satoyama landscape.

\subsection{Interactions Between Biodiversity Loss and Ecosystem Services in Satoyama Landscape}

Studies described above suggest that industrialisation, urbanization, and globalization, as well as innovation of agricultural technology $[19,26,33,86,87]$, have dramatically changed the traditional harmonious human-nature relationship [13] into a complicated status of partial upgrading, but overall degradation, of habitats in Japan. As a traditional rural landscape, Satoyama landscape used to be the life-supporting backyard of woodland, the beautiful homeland of ancestors, and the hotspot of ecosystem services and biodiversity [33]. It has also changed continuously with the development of economy and society, from the slow sustainable use period to the rapid overuse and underuse periods.

First of all, during the early 19th century (the late Edo and early Meiji eras), the whole society was entirely dependent on bio-resources and resulted in the overuse of Satoyama landscape, which caused serious soil erosion [88] and the decline of some species [89]. That was the first biodiversity crisis brought about by human activities and development [32]. Following the beginning of modern industrialization since the 1960s, the significant progress in economy and technology resulted in the development of industry that caused the immigration of younger generations from rural to urban areas in Japan. The aging problems of farmers in according with the higher purchasing power of citizens objectively increased the prices of ecosystem services and goods in the national market. The import of ecosystem services and goods in the international market caused the abandonment of Satoyama landscape (the second biodiversity crisis), and then led to the decreasing of ecosystem services as well as habitat loss for species. Wide use of fossil fuels and chemical fertilizers, and consolidation of agricultural facilities in industrialized agriculture can provide more food for humans, but they caused 
the fragmentation of habitats and the simplification of crop plants, as well as the decrease of other ecosystem services. Furthermore, global climate changes and degradation of Satoyama landscape led to the invasion of alien species (the third crisis). Eventually, the loss and fragmentation of habitats caused the biodiversity crises in Satoyama landscape of Japan (Figure 6).

\subsection{Interactions among Biodiversity Loss, Ecosystem Services and Goods, and Human Well-Being in Rice Production}

Compared to the habitat loss caused by abandonment of forests and grassland, the habitat loss and fragmentation in rice paddy fields and dry land are more serious, because the former can be easily recovered by re-utilization with traditional management. However, the latter completely modified the surface and underground water and nutrient flows by the construction of consolidated infrastructures that reduced the eco-hydrological connectivity and water regulating services. The dis-connectivity of water and nutrients flows within Satoyama landscape resulted in drier and poorer soils, which then caused the decrease of plants depending on more soil moisture and nutrients, and at last reduced biodiversity (Figure 7). Why did people or agricultural technological departments consolidate the farmland infrastructure but neglect the impacts of biodiversity? Taking the consolidation of rice paddy fields and rice production as an example, according to [90], the abandoned rice paddy was increased while the total planting area, the production, and consumption were all decreased continuously, but the rice yield is rising because of the consolidation of agricultural infrastructure. Indeed, $61.3 \%$ of rice paddy fields have been consolidated till 2007, which saved the working time for rice cultivation from $1463 \mathrm{hr} / \mathrm{ha}$ in 1963 to $285 \mathrm{hr} / \mathrm{ha}$ in 2007 . This means that the consolidation of rice paddy fields can increase rice yield and reduce labor for rice cultivation simultaneously; namely, it can increase the provisioning services of rice products as well as human well-being. There is no doubt that pursuing higher human well-being is one of the ultimate aims of economic development, but biodiversity loss will ultimately hurt human well-being in the future. Therefore, the trade-off between human well-being and biodiversity conservation in Satoyama landscape still needs further study via interdisciplinary approaches.

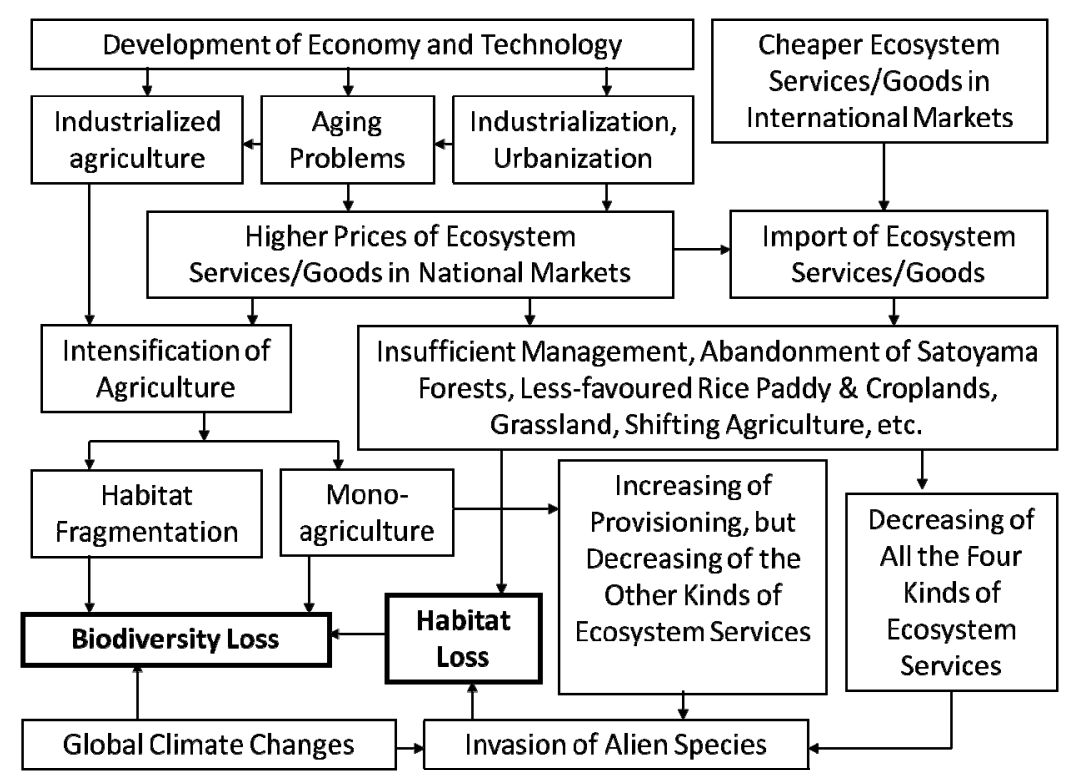

Figure 6. Interactions among biodiversity loss and ecosystem services in Satoyama landscape of Japan. 


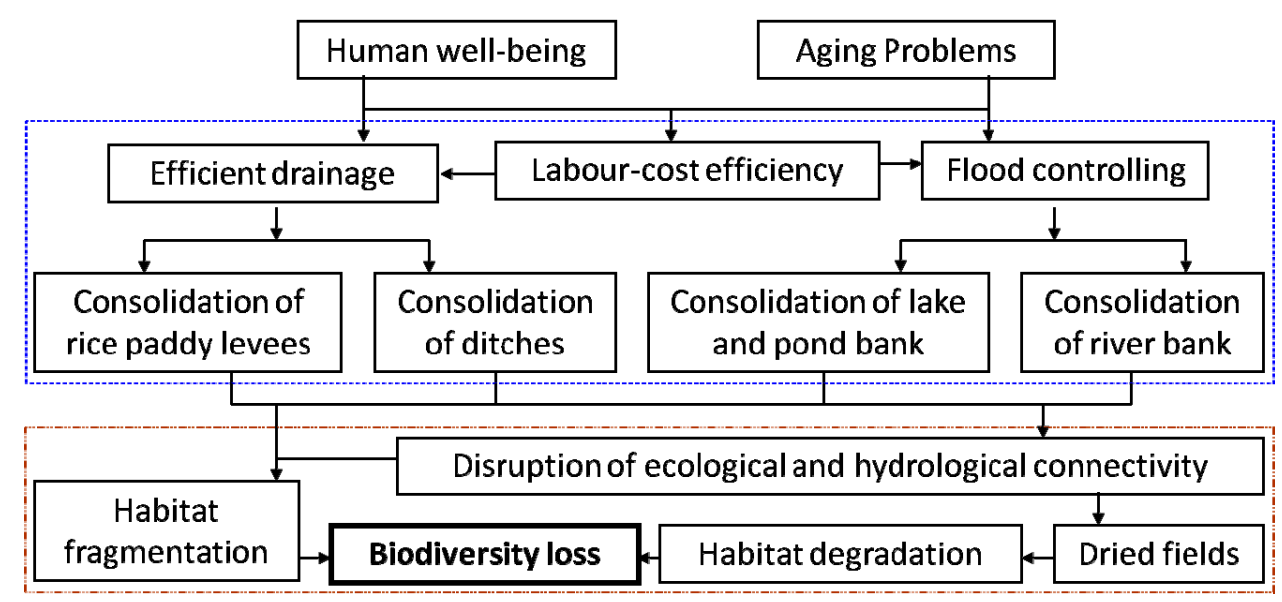

Figure 7. Interactions among biodiversity loss, ecosystem services and goods, and human well-being in rice production.

\subsection{Current Strategies and Perspective of Management in Satoyama Landscape}

Nowadays, following the emergence of biodiversity loss, global climate change, and other environmental problems, the negative impacts of Satoyama issues captured a lot of concern from the scientific community, government, and society in Japan, thus eventually inducing the resurgence of interest in pre-industrial traditional Satoyama landscape [20]. Therefore, recently numerous assessment reports, strategies, and actions were formulated by researchers, policy-makers, and government departments [91-93], such as the "Satoyama Initiative", the "Sub-global assessment of Satoyama and Satoumi in Japan", "The 10th Conference of the Parties (COP 10) to the Convention on Biological Diversity (CBD)" and the following related reports: "Satoyama: the Japanese countryside landscape" [94]; "The Third National Biodiversity Strategy of Japan" [32]; "Satoyama-Satoumi Ecosystems and Human Well-being: Socio-ecological Production Landscapes of Japan" [95]; "Biodiversity is Life, Biodiversity is our Life: The National Biodiversity Strategy of Japan 2010" [64]; and "Sustainable use of biological diversity in socio-ecological production landscapes. Background to the Satoyama Initiative for the benefit of biodiversity and human well-being" [96]. It should be noted that the most essential perspective of these reports and policies are to find the dynamically balanced interactions between human and nature in the long term, and to rebuild a sustainable low-carbon, resource-circulating, and nature-harmonious society with an eye on resilience enhancement and optimization of biodiversity conservation [13]. To address it, structuring of a more effective management system must be promoted according to the natural and social characteristics under the current socioeconomic conditions. At present, there is a real valuable action of environment-friendly farming, carried out in Sado island of Niigata Prefecture from 2004. Through winter-flooding of rice paddy fields, together with organic farming and fish ladders, it provided a suitable habitat for many aquatic species, such as crested ibises, loaches, and fishes. The rice growing there is given the certification of "Creating villages coexisting with crested ibises" and then is traded at higher prices than ordinary ones. In this system, biodiversity, ecosystem services, and human well-being are all integrated into a multifunctional landscape, which can be used as a revitalizing model in rural development of Japan.

\section{Conclusion and Future Challenges}

Although the concept of Satoyama landscape varies with researchers, it is usually defined as the traditional rural area of Japan that is a mosaic formed by multiple components, including secondary forests, rice paddies, settlements, water areas, and so on. The second biodiversity crisis in Japan has happened in Satoyama landscape and resulted in the loss of biodiversity and the decrease of ecosystem services. The primary reason is the abandonment and industrialization of secondary forests, rice paddy fields, and dry land via abandonment of traditional management that is the maintaining 
mechanism of rich biodiversity and ecosystem service provision. Both transition of traditional arable farming in favour of more intensive methods, and land abandonment, have resulted in biodiversity loss due to disappearance and fragmentation of habitats. The interactions among biodiversity loss, ecosystem services, and human well-being under the current social-economic situations showed that: (1) The social-economic change, such as aging problems and import of ecosystem services and goods from international markets, resulted in the abandonment of Satoyama landscape. (2) To get more provisioning ecosystem services from farmland but decrease the labour cost of crop cultivation, consolidation of rice paddy levees, irrigating and drainage systems, rivers, and pond banks caused the dis-connectivity of water and nutrient flows within Satoyama landscape, thus leaded to the fragmentation and loss of habitats for many aquatic species. Although many strategies and policies had been conducted to counter the Satoyama issues since the 1990s by Japanese government and NGOs, more things should be done to revitalize the Satoyama landscape.

First, to deal with the local biodiversity crisis resulted from national and international ecosystem service markets, further studies must be done on the mechanisms of balancing local and international markets for the demand and supply of ecosystem services. In fact, from the trade-off view of ecosystem services, excessive dependence on the external input of ecosystem services will result in lose-lose effects on both the input and output countries, because the input country will lose ecosystem services by underuse and the output country will lose by overuse. This international trade-off of ecosystem services is common between developed and developing countries, with the former suffering from underuse and the latter from overuse. Under this background, addressing the Satoyama issues can benefit human wellbeing in the world because ecosystem services are the basis of human wellbeing [6]. In addition, there is an urgent need for better and more integrated global- and regional-scale scientific research on biodiversity, ecosystem services, and human wellbeing [6,97].

Second, Satoyama landscape faces the intensive use of fertile area via consolidation of rice paddy levees, river banks, ditch banks, and pond and lake banks, as well as higher input of chemical fertilizers and pesticides. Intensified mono-agriculture leaded to the habitat fragmentation of species by cutting off the connectivity of water and nutrient flows among neighbouring patches. Research on the mechanisms of environmental flows and habitat fragmentation will play an important role in solving loss of biodiversity and ecosystem services in Satoyama landscapes. At the same time, reuse of Satoyama landscape with silvicultural practices should be limited to a specific extent for significant and specific conservation purposes, because it can decrease plant species diversity remarkably [98].

Third, since every culture is rooted in the utilizing system of materials and resources in the surrounding environment, the revitalization and reutilization of Satoyama landscape by traditional management strategies can serve as a way to preserve the essence of Japanese culture for future generations $[13,99]$. Therefore, retrieval of traditional knowledge on subsistence agriculture and ecosystem management is a forefront challenge that must be faced [92], especially the social norms for irrigating (ground) water management [100]. Actually, it is a common view worldwide that reintegration of traditional agricultural knowledge and new ecological knowledge into more ecologically designed agricultural systems can benefit biodiversity and ecosystem services simultaneously [11]. However, due to traditional management of ecosystems being labour-intensive works which are hard for farmers, while industrialized mono-agriculture is highly dependent on machines and pesticides, which are bad for ecosystems and biodiversity [12], how to balance the farmer's wellbeing and biodiversity is another challenge that must be solved in the future to slow down global changes.

Fourth, future research should pay more attention to the studies at the landscape scale considering pattern-process relationships, apart from current studies at species and ecosystem levels. Moreover, future international comparison of similar cultural landscapes should concern broader aspects of productive practices than only agro-forestry [101]. Finding the sustainable mechanism of these landscapes eventually can benefit the conservation of bio-cultural diversities and help to face Satoyama issues. Certainly, well-developed systematic laws and policies are the legal guarantee for coping with Satoyama issues [92]. 
At last, studies showed that habitat heterogeneity affects the level of biodiversity in agricultural landscapes $[1,7,102,103]$. Both abandonment and intensification of Satoyama elements cause biodiversity loss. Therefore, how to make an intermediate disturbance to reach the highest amount of biodiversity is a key scientific question in the conservation of Satoyama landscape. Some detailed mechanisms in maintaining biodiversity may help in dealing with it. For instance, forest cover has positive effects on the richness and abundance of edge and woodland bird species. Future research needs to quantify the responses of multiple species to changes in edge density and forest cover, in order to develop "appropriate" conservation strategies [44] to meet the trade-offs between conservation of different taxonomic groups in Satoyama landscapes.

Beside the above Satoyama research, more and more studies worldwide have revealed that the multiple interacting mechanisms among natural, semi-natural, and agricultural ecosystems have eventually contributed to biodiversity and ecosystem services at the complex landscape scale $[9,15,16]$, and new methods to quantify or measure these interactions and their effects in specific landscapes will be a scientific hotspot. Perhaps the newly reused principles and methods of landscape entropy can help to quantify the managing mechanism of heterogeneity, pattern, and process dynamics in complex landscapes such as Satoyama [104-107].

Author Contributions: Y.J. and T.O. designed and wrote the paper; Y.D. redrew some figures, and Z.Z. edited the tables and references.

Funding: This study was funded by the Environment Research and Technology Development Fund of Japan's Ministry of the Environment (E-0902), by the National Natural Science Foundation of China (grant numbers 41761115, 41271203).

Acknowledgments: The authors thank the three anonymous reviewers for the very helpful comments and suggestions.

Conflicts of Interest: The authors declare no conflict of interest.

\section{References}

1. Benton, T.G. Managing farming's footprint on biodiversity. Science 2007, 315, 341-342. [CrossRef] [PubMed]

2. Green, R.E.; Cornell, S.J.; Scharlemann, J.P.W.; Balmford, A. Farming and the fate of wild nature. Science 2005, 307, 550-555. [CrossRef]

3. Swift, M.J.; Izac, A.M.N.; van Noordwijk, M. Biodiversity and ecosystem services in agricultural landscapes-are we asking the right questions? Agric. Ecosyst. Environ. 2004, 104, 113-134. [CrossRef]

4. Antrop, M. Why landscapes of the past are important for the future. Landsc. Urban Plan. 2005, 70, 21-34. [CrossRef]

5. Harrop, S. Traditional agricultural landscapes as protected areas in international law and policy. Agric. Ecosyst. Environ. 2007, 121, 296-307. [CrossRef]

6. MA (Millennium Ecosystem Assessment). Ecosystem and Human Well-Being: Synthesis; Island Press: Washington, DC, USA, 2005.

7. Palomo-Campesino, S.; González, J.A.; García-Llorente, M. Exploring the Connections between Agroecological Practices and Ecosystem Services: A Systematic Literature Review. Sustainability 2018, 10, 4339. [CrossRef]

8. Wu, J.G. Landscape sustainability science: Ecosystem services and human well-being in changing landscapes. Landsc. Ecol. 2013, 28, 999-1023. [CrossRef]

9. Tscharntke, T.; Clough, Y.; Wanger, T.C.; Jackson, L.; Motzke, I.; Perfecto, I.; Vandermeer, J.; Whitbread, A. Global food security, biodiversity conservation and the future of agricultural intensification. Biol. Conserv. 2012, 151, 53-59. [CrossRef]

10. Altieri, M.A. Globally Important Ingenious Agricultural Heritage Systems (GIAHS): Extent, significance, and implications for development. In Proceedings of the GIAHS 2nd International Workshop, Rome, Italy, 7-9 June 2004; United Nations Food and Agriculture Organisation: Rome, Italy, 2004.

11. Matson, P.A.; Parton, W.J.; Power, A.G.; Swift, M.J. Agricultural intensification and ecosystem properties. Science 1997, 277, 504-509. [CrossRef] 
12. Tilman, D. Global environmental impacts of agricultural expansion: The need for sustainable and efficient practices. Proc. Natl. Acad. Sci. USA 1999, 96, 5995-6000. [CrossRef]

13. Takeuchi, K. Rebuilding the relationship between people and nature: The Satoyama Initiative. Ecol. Res. 2010, 25, 891-897. [CrossRef]

14. MacDonald, D.; Crabtree, J.R.; Wiesinger, G.; Dax, T.; Stamou, N.; Fleury, P.; Gutierrez Lazpita, J.; Gibon, A. Agricultural abandonment in mountain areas of Europe: Environmental consequences and policy response. J. Environ. Manag. 2000, 59, 47-69. [CrossRef]

15. Wezel, A.; Casagrande, M.; Celette, F.; Vian, J.-F.; Ferrer, A.; Peigné, J. Agroecological practices for sustainable agriculture: A review. Agron. Sustain. Dev. 2014, 34, 1-20. [CrossRef]

16. Godfray, H.C.J.; Beddington, J.R.; Crute, I.R.; Haddad, L.; Lawrence, D.; Muir, J.F.; Pretty, J.; Robinson, S.; Thomas, S.M.; Toulmin, C. Food security: The challenge of feeding 9 billion people. Science 2010, 327, 812-818. [CrossRef] [PubMed]

17. Washitani, I. Traditional sustainable ecosystem "SATOYAMA" and biodiversity crisis in Japan conservation ecological perspective. Glob. Environ. Res. 2001, 5, 119-133.

18. Kobori, H.; Primac, R. Participatory conservation approaches for Satoyama, the traditional forest and agricultural landscape of Japan. AMBIO 2003, 32, 307-311. [CrossRef]

19. Takeuchi, K.; Brown, R.D.; Washitani, I.; Tsunekawa, A.; Yokohari, M. (Eds.) Satoyama: The Traditional Rural Landscape of Japan; Springer: Tokyo, Japan, 2003.

20. Kumar, B.M.; Takeuchi, K. Agroforestry in the Western Ghats of peninsular India and the Satoyama landscapes of Japan: A comparison of two sustainable land use systems. Sustain. Sci. 2009, 4, 215-232. [CrossRef]

21. Maeda, K.; Tanaka, T.; Hotaek, P.; Hattori, S. Spatial distribution of soil structure in a suburban forest catchment and its effect on spatio-temporal soil moisture and runoff fluctuations. J. Hydrol. 2006, 321, 232-256. [CrossRef]

22. Morimoto, J.Y.; Oshida, J. Dynamic changes of native Rhododendron colonies in the urban fringe of Kyoto city in Japan detecting the long-term dynamism for conservation of secondary nature. Landsc. Urban Plan. 2005, 70, 195-204. [CrossRef]

23. Iwata, Y.; Fukamachi, K.; Morimoto, Y. Public perception of the cultural value of Satoyama landscape types in Japan. Landsc. Ecol. Eng. 2011, 7, 173-184. [CrossRef]

24. Berglund, B.E. Satoyama, Traditional Farming Landscape in Japan, Compared to Scandinavia. Jpn. Rev. 2008, 20, 53-68. [CrossRef]

25. Mukai, Y.; Baba, N.; Ishii, M. The water system of traditional rice paddies as an important habitat of the giant water bug, Lethocerus deyrollei (Heteroptera: Belostomatidae). J. Insect Conserv. 2005, 9, 121-129. [CrossRef]

26. Fukamachi, K.; Oku, H.; Nakashizuka, T. The change of a Satoyama landscape and its causality in Kamiseya, Kyoto Prefecture, Japan between 1970 and 1995. Landsc. Ecol. 2001, 16, 703-717. [CrossRef]

27. Tokoro, M. Studies on Forestry in Early Modern Times; Yoshikawa Kohbunka: Tokyo, Japan, 1980; p. 887.

28. Shidei, T. Value of Forests; Kokin: Tokyo, Japan, 1973. (In Japanese)

29. Tabata, H. The Nature of Satoyama; Hoikusha Publishing Co. Ltd.: Osaka, Japan, 1997. (In Japanese)

30. Fukamachi, K.; Nakashizuka, I.T. Landscape Patterns and Plant Species Diversity of Forest Reserves in the Kanto Region, Japan. Vegetatio 1996, 124, 107-114. [CrossRef]

31. Shidei, T. Notes on SATOYAMA. J. Kansai Organ. Nat. Conserv. 2000, 22, 71-77.

32. MEGJ (Ministry of the Environment, Government of Japan). The Third National Biodiversity Strategy of Japan. 2008. Available online: http://www.env.go.jp/en/focus/attach/071210-e.pdf (accessed on 15 September 2011).

33. Morimoto, Y. What is Satoyama? Points for discussion on its future direction. Landsc. Ecol. Eng. 2011, 7, 163-171. [CrossRef]

34. Higuchi, H.; Primack, R.B. Conservation and management of biodiversity in Japan: An introduction. Boil. Conserv. 2009, 142, 1881-1883. [CrossRef]

35. Amano, T. Conserving bird species in Japanese farmland Past achievements and future challenges. Boil. Conserv. 2009, 142, 1913-1921. [CrossRef]

36. Connell, J.H. Diversity in tropical rain forests and coral reefs. Science 1978, 199, 1302-1310. [CrossRef]

37. Turner, M.G. Disturbance and landscape dynamics in a changing world. Ecology 2010, 91, $2833-2849$. [CrossRef] 
38. Matsuda, H.; Hada, Y.; Moriyama, A.; Washitani, I. "SATOYAMA" and Environmental Impact Assessment for the World Exposition 2005 A Conservation Ecological Evaluation. Glob. Environ. Res. 2001, 5, 183-191.

39. Iiyama, N.; Kamada, M.; Nakagoshi, N. Ecological and sociale valuation of landscape in a rural area with terraced paddies in southwestern Japan. Landsc. Urban Plan. 2005, 73, 60-71. [CrossRef]

40. Kato, M. "SATOYAMA" and Biodiversity Conservation "SATOYAMA" as Important Insect Habitats. Glob. Environ. Res. 2001, 5, 135-149.

41. Leksono, A.S.; Takada, K.; Nakagoshi, N.; Nakamura, K. Species composition of Modellidae and Cerambycidae (Coleoptera) in a coppice woodland. J. For. Res. 2006, 11, 61-64. [CrossRef]

42. Ueda, A. Administrative information: Spatial distribution of Satochi-Satoyama in Japan and its characteristics. J. Jpn. Inst. Landsc. Arch. 2002, 65, 269-270.

43. Kadoya, T.; Washitani, I. The Satoyama Index: A biodiversity indicator for agricultural landscapes. Agric. Ecosyst. Environ. 2011, 140, 20-26. [CrossRef]

44. Amano, T.; Kusumoto, Y.; Tokuoka, Y.; Yamada, S.; Kim, E.Y.; Yamamoto, S. Spatial and temporal variations in the use of rice-paddy dominated landscapes by birds in Japan. Boil. Conserv. 2008, 141, 1704-1716. [CrossRef]

45. Amano, T.; Yamaura, Y. Ecological and life-history traits related to range contractions among breeding birds in Japan. Boil. Conserv. 2007, 137, 271-282. [CrossRef]

46. Maeda, T. Patterns of bird abundance and habitat use in rice fields of the Kanto Plain, central Japan. Ecol. Res. 2001, 16, 569-585. [CrossRef]

47. Yamazaki, M.; Hamada, Y.; Kamimoto, N.; Momii, T.; Kimura, M. Spatial distribution of aquatic organisms in a paddy field during the off-crop season under drained conditions. Edaphologia 2001, 68, 23-31.

48. Yokota, H. The effect of tillage on the population density of small Oligochaeta (Enchytraeidae and Naididae) in paddy field, Japan. Jpn. J. Soil Sci. Plant Nutr. 2002, 73, 33-39, (In Japanese with English Summary).

49. Maleque, M.A.; Maeto, K.; Makino, S.; Goto, H.; Tanaka, H.; Hasegawa, M.; Miyamota, A. A chronosequence of understorey parasitic wasp assemblages in secondary broad-leaved forests in a Japanese 'satoyama' landscape. Insect Conserv. Divers. 2010, 3, 143-151. [CrossRef]

50. Nakagoshi, N.; Hong, S.K. Vegetation and Landscape Ecology of East Asian "SATOYAMA". Glob. Environ. Res. 2001, 5, 171-181.

51. Iida, S.; Nakashizuka, T. Forest fragmentation and its effect on species diversity in suburban coppice forests in Japan. For. Ecol. Manag. 1995, 73, 197-210. [CrossRef]

52. Koyanagi, T.; Kusumoto, Y.; Yamamoto, S.; Okubo, S.; Takeuchi, K. Historical impacts on linear habitats: The present distribution of grassland species in forest-edge vegetation. Boil. Conserv. 2009, 142, 1674-1684. [CrossRef]

53. Kagawa, Y.; Maeto, K. Spatial population structure of the predatory ground beetle Carabus yaconinus (Coleoptera: Carabidae) in the mixed farmland-woodland satoyama landscape of Japan. Eur. J. Ėntomol. 2009, 106, 385-391. [CrossRef]

54. Koyanagi, T.; Kusumoto, Y.; Yamamoto, S.; Ohkuro, T.; Takeuchi, K. Comparison of the species compositions between past and present semi-natural Miscanthus sinensis grassland in the Kanto Plain. J. Jpn. Inst. Landsc. Arch. 2007, 70, 439-444, (In Japanese with English Summary). [CrossRef]

55. Hippa, H.; Kjaerandsen, J. First fungus gnats of genus Manota Williston (Diptera: Mycetophilidae) from Japan. Ėntomol. Sci. 2010, 13, 226-233. [CrossRef]

56. Yamamoto, S.; Kusumoto, Y.; Shiina, M.; Ide, M.; Okushima, S. Biotope evaluation in yatsu area based on plant communities, butterflies and landscape structure. J. Jpn. Agric. Syst. Soc. 2007, 23, 1-10, (In Japanese with English Summary).

57. Ueta, M.; Kurosawa, R.; Matsuno, H. Habitat Loss and the Decline of Grey-faced Buzzards (Butastur indicus) in Tokyo, Japan. J. Raptor Res. 2006, 40, 52-56. [CrossRef]

58. Hirasawa, M.; Kanda, E.; Takatsuki, S. Seasonal food habits of the raccoon dog at a western suburb of Tokyo. Mamm. Study 2006, 31, 9-14. [CrossRef]

59. Katoh, K.; Sakai, S.; Takahashi, T. Factors maintaining species diversity in satoyama, a traditional agricultural landscape of Japan. Boil. Conserv. 2009, 142, 1930-1936. [CrossRef]

60. Cetinkaya, G. Challenges for the Maintenance of Traditional Knowledge in the Satoyama and Satoumi Ecosystems, Noto Peninsula, Japan. Hum. Ecol. Rev. 2009, 16, 27-40. 
61. Putrare, E.; Nakamura, K. Foraging ecology of a local wild bee community in an abandoned Satoyama system in Kanazawa, Central Japan. Èntomol. Res. 2009, 39, 99-106. [CrossRef]

62. Morimoto, J.; Kondo, T.; Miyauchi, T. Satoyama-satoumi sub-global assessment in Japan and involvement of the Hokkaido Cluster. Landsc. Ecol. Eng. 2009, 5, 91-96. [CrossRef]

63. Natori, Y.; Chenoweth, R. Differences in rural landscape perceptions and preferences between farmers and naturalists. J. Environ. Psychol. 2009, 28, 250-267. [CrossRef]

64. NCBMEGJ (Nature Conservation Bureau, Ministry of the Environment, Government of Japan). Biodiversity Is Life, Biodiversity Is Our Life: The National Biodiversity Strategy of Japan 2010; Ministry of the Environment, Government of Japan: Tokyo, Japan, 2010.

65. Fukamachi, K.; Miki, Y.; Oku, H.; Miyoshi, I. The biocultural link: Isolated trees and hedges in Satoyama landscapes indicate a strong connection between biodiversity and local cultural features. Landsc. Ecol. Eng. 2011, 7, 195-206. [CrossRef]

66. Kamada, M.; Nakagoshi, N. Influence of cultural factors on landscapes of mountainous farm villages in western Japan. Landsc. Urban Plan. 1997, 37, 85-90. [CrossRef]

67. Osumi, K.; Ikeda, S.; Okamoto, T. Vegetation patterns and their dependency on site conditions in the pre-industrial landscape of north-eastern Japan. Ecol. Res. 2003, 18, 753-765. [CrossRef]

68. Moriyama, H. What Is Conservation of Nature? Noh-Bun-Kyo: Tokyo, Japan, 1988. (In Japanese)

69. Ichinose, T.; Asmiwyati, I.G.A.A.R.; Kataoka, M.; Arifin, N.H.S. Land-use change and irrigation systems in the agricultural landscape of terraced paddy fields in Awaji Island, central Japan. Landsc. Ecol. Eng. 2007, 3, 171-177. [CrossRef]

70. Uematsua, Y.; Kogaa, T.; Mitsuhashi, H.; Ushimarua, A. Abandonment and intensified use of agricultural land decrease habitats of rare herbs in semi-natural grasslands. Agric. Ecosyst. Environ. 2010, 135, 304-309. [CrossRef]

71. Nakamura, Y. Conservation of butterflies in Japan: Status, actions and strategy. J. Insect Conserv. 2011, 15, 1-2. [CrossRef]

72. Ohwaki, A.; Nakamura, K.; Tanabe, S.I. Butterfly assemblages in a traditional agricultural landscape importance of secondary forests for conserving diversity life history specialists and endemics. Biodivers. Conserv. 2007, 16, 1521-1539. [CrossRef]

73. Kadoya, T.; Suda, S.; Washitani, I. Dragonfly crisis in Japan: A likely consequence of recent agricultural habitat degradation. Boil. Conserv. 2009, 142, 1899-1905. [CrossRef]

74. Ohba, N. The Genji-Firefly; Japanese Insects Series; Bun'ichi Sogo Press: Tokyo, Japan, 1988; Volume 12. (In Japanese)

75. Takeda, M.; Amano, T.; Katoh, K.; Higuchi, H. The habitat requirement of the Genji-firefly Luciola cruciata (Coleoptera: Lampyridae), a representative endemic species of Japanese rural landscapes. Biodivers. Conserv. 2006, 15, 191-203. [CrossRef]

76. Hirano, T.; Kimijima, M.; Kobori, M. Hunting habitat and diet of Grey-faced Buzzards in Watarase Marsh. Strix 2004, 22, 45-58, (In Japanese with English Summary).

77. Okuro, T.; Jiao, Y.; Yamamoto, S. Integrated Assessment of Biodiversity and Multi-functionality of Satoyama Landscapes. Glob. Environ. Res. 2012, 16, 205-212.

78. Kadowaki, S.; Murayama, T.; Kojima, Y. Differences in the utilization of cultivated and uncultivated paddy fields as hunting grounds by the grey-faced Buzzard-eagle, Butastur indicus. J. Yamashina Inst. Ornithol. 2007, 39, 19-26. [CrossRef]

79. Azuma, A. Conservation of Grey-faced Buzzard Butastur indicus and its habitat: A landscape ecological study. Bull. Abiko City Mus. Birds 2004, 12, 1-119, (In Japanese with English Summary).

80. Kobayashi, Y.; Koike, F. Separating the effects of land-use history and topography on the distribution of woody plant populations in a traditional rural landscape in Japan. Landsc. Urban Plan. 2010, 95, 34-45. [CrossRef]

81. Yamada, S.; Okubo, S.; Kitagawa, Y.; Takeuchi, K. Restoration of weed communities in abandoned rice paddy fields in the Tama Hills, central Japan. Agric. Ecosyst. Environ. 2007, 119, 88-102. [CrossRef]

82. Fujioka, M.; Lane, S.J. The impact of changing irrigation practices in rice fields on frog population of the Kanto Plain, central Japan. Ecol. Res. 1997, 12, 101-108. [CrossRef]

83. Lane, S.J.; Fujioka, M. The impact of changes in irrigation practices on the distribution of foraging egrets and herons (Ardeidae) in the rice fields of central Japan. Boil. Conserv. 1998, 83, 221-230. [CrossRef] 
84. Fukamachi, K.; Oku, H.; Miyake, A. The relationships between the structure of paddy levees and the plant species diversity in cultural landscapes on the west side of Lake Biwa, Shiga, Japan. Landsc. Ecol. 2005, 1, 191-199. [CrossRef]

85. Washitani, I. Distribution of phydorophytes in Shishidzuka-Ooike Pond Site. In Shishidzuka Nature and History Club; Reports of the Investigation on the Natural Environment of Shishidzuka-Ooike Area: Ibaraki, Tokyo, Japan, 1995; pp. 123-128. (In Japanese)

86. Miyamotoa, A.; Sano, M. The influence of forest management on landscape structure in the cool-temperate forest region of central Japan. Landsc. Urban Plan. 2008, 86, 248-256. [CrossRef]

87. Takeuchi, K. Nature Conservation Strategies for the "SATOYAMA" and "SATOCHI", Habitats for Secondary Nature in Japan. Glob. Environ. Res. 2001, 5, 193-198.

88. Ichikawa, K.; Okubo, N.; Okubo, S.; Takewuchi, K. Transition of the satoyama landscape in the urban fringe of the Tokyo metropolitan area from 1880 to 2001. Landsc. Urban Plan. 2006, 78, 398-410. [CrossRef]

89. Inoue, K. Present Status of Endangered Orchids in "SATOYAMA" Area. Glob. Environ. Res. 2001, 5, $163-168$.

90. MAFF (Ministry of Agriculture, Forestry and Fisheries) "Statistics on Crops" and "Food Balance Sheet". Available online: http:/ /www.maff.go.jp/e/annual_report/2009/index.html (accessed on 15 September 2009).

91. Kobori, H. Current trends in conservation education in Japan. Boil. Conserv. 2009, 142, 1950-1957. [CrossRef]

92. Takahashi, M.A. Overview of the structure and the challenges of Japanese wildlife law and policy. Boil. Conserv. 2009, 142, 1958-1964. [CrossRef]

93. Yokohari, M.; Bolthouse, J. Planning for the slow lane: The need to restore working greenspaces in maturing contexts. Landsc. Urban Plan. 2011, 100, 421-424. [CrossRef]

94. MEGJ (Ministry of the Environment, Government of Japan). Satoyama: The Japanese Countryside Landscape; Nature Conservation Bureau, Ministry of the Environment, Government of Japan: Tokyo, Japan, 2008.

95. JSSA (Japan Satoyama Satoumi Assessment). Satoyama-Satoumi Ecosystems and Human Well-Being: Socio-Ecological Production Landscapes of Japan-Summary for Decision Makers; United Nations University: Tokyo, Japan, 2010.

96. Bélair, C.; Ichikawa, K.; Wong, B.Y.L.; Mulongoy, K.J. (Eds.) Sustainable Use of Biological Diversity in Socio-Ecological Production Landscapes. Background to the 'Satoyama Initiative for the Beneft of Biodiversity and Human Well-Being'; Technical Series No. 52; Secretariat of the Convention on Biological Diversity: Montreal, QC, Canada, 2010; 184p.

97. Djoghlaf, A. From SATOYAMA to managing global biodiversity Foreword. Ecol. Res. 2010, 25, 889-890. [CrossRef]

98. Saeki, I. Effects of tree cutting and mowing on plant species composition and diversity of the wetland ecosystems dominated by the endangered maple, Acer pycnanthum. For. Ecol. Manag. 2007, 242, 733-746. [CrossRef]

99. Horiuchi, M.; Fukamachi, K.; Oku, H. Reed community restoration projects with citizen participation an example of the practical use of Satoyama landscape resources in Shiga Prefecture, Japan. Landsc. Ecol. Eng. 2010, 7, 217-222. [CrossRef]

100. Yamamoto, S. Groundwater management in rice terraces: A case study of a lakeside community in Shiga Prefecture, Japan. Local Environ. 2008, 13, 449-460. [CrossRef]

101. García-Frapolli, E.; Ayala-Orozco, B.; Bonilla-Moheno, M.; Espadas-Manrique, C.; Ramos-Fernández, G. Biodiversity conservation, traditional agriculture and ecotourism: Land cover/land use change projections for a natural protected area in the northeastern Yucatan Peninsula, Mexico. Landsc. Urban Plan. 2007, 83, 137-153. [CrossRef]

102. Benton, T.G.; Vickery, J.A.; Wilson, J.D. Farmland biodiversity: Is habitat heterogeneity the key? Trends Ecol. Evol. 2003, 18, 182-188. [CrossRef]

103. Bennett, A.F.; Radford, J.Q.; Haslem, A. Properties of land mosaics: Implications for nature conservation in agricultural environments. Boil. Conserv. 2006, 133, 250-264. [CrossRef]

104. Cushman, S.A. Thermodynamics in landscape ecology: The importance of integrating measurement and modeling of landscape entropy. Landsc. Ecol. 2015, 30, 7-10. [CrossRef]

105. Cushman, S.A. Calculating the configurational entropy of a landscape mosaic. Landsc. Ecol. 2016, 31, 481-489. [CrossRef] 
106. Gao, P.C.; Zhang, H.; Li, Z.L. A hierarchy-based solution to calculate the configurational entropy of landscape gradients. Landsc. Ecol. 2017, 32, 1133-1146. [CrossRef]

107. Gao, P.C.; Zhang, H.; Li, Z.L. An efficient analytical method for computing the Boltzmann entropy of a landscape gradient. Trans. GIS 2018, 22, 1046-1063. [CrossRef] 